\title{
Government Intervention in Malaysian Housing Market
}

\author{
Normi Abdul Asis,Wilson Rangga Anthony Jiram, Ahmad Ariffian Bujang
}

\begin{abstract}
Housing is a basic need for society to improve their quality of life and as important assets for the country's economic. Malaysian Housing Policy has focused and concentrated to provide adequate housing supply for the targeted group, especially for the bottom 40\% income earner. The urbanisation process creates the socio-economic changes has led to the increases in demand for housing. The previous study stated that there was a discrepancy between demand and supply in housing market resulted from rising trend in house price compared to the household income, thus leading to market imperfection. Thus, this paper attempted to explore the government intervention in the housing market. In a nutshell, government intervention is necessary to correct the market imperfection through policies and project implementations. There is a need to improve market efficiency and review the delivery of both supply and demand in the housing market.
\end{abstract}

Keywords : government intervention, housing market, market efficiency

\section{INTRODUCTION}

According to Maslow's Hierarchy Pyramid, housing is a basic need for society [1,2]. Owning homes is a dream for everyone to improve their quality of life. Housing is the biggest component of most household's wealth, therefore, it has a big impact on the economy. The affordability in purchasing a house is measured on their ability to repay the housing loan. Affordability primarily depends on housing expenditure and income distribution [3]. The affordability simply refers to ability to buy, to pay and household income distribution $[1,4,5,6,7,8]$. This shows that household income distribution influences their ability to purchase even a house $[9,10]$.

Under the Fifth Malaysian Plan, allocation and provision of the low-cost house have become a government priority. Malaysian Housing Policy has focused to provide adequate housing supply for the low-income group. The Malaysian government has been actively intervened the housing market by undertaking various housing programme [11]. Government agencies have encouraged the private sector to develop affordable housing during the Tenth Malaysian Plan period, and the Malaysian government has continuing the efforts and underlined several affordable housing programmes. Affordable housing for target groups is supported by several government initiatives, such as Rumah

Revised Manuscript Received on October15, 2019

* Correspondence Author

Normi Abdul Asis, Department of Real Estate, Universiti Teknologi Malaysia, Johor Bahru, Malaysia. Email: asisnormi@gmail.com

Wilson Rangga Anthony Jiram*, Department of Real Estate, Universiti Teknologi Malaysia, Johor Bahru, Malaysia. Email: rangga@utm.my

Ahmad Ariffian Bujang, Department of Real Estate, Universiti Teknologi Malaysia, Johor Bahru, Malaysia.Email: ahmadariffian@utm.my
Mesra Rakyat 1Malaysia (RMR1M), Perumahan Rakyat 1Malaysia (PR1MA), Program Perumahan Rakyat (PPR), Rumah Wilayah Persekutuan (RUMAWIP), Program Bantuan Rumah (PBR), Rumah Selangorku and 1Malaysia Civil Servants Housing (PPA1M). Nevertheless, the development of affordable housing seems inadequate to cater to community needs.

In Johor Bahru, the urbanisation process creates the socio-economic changes has lead to the increases in demand for housing. A rising trend in house prices affected the household chances to buy a house $[9,10]$. According to Quigley \& Raphael (2004), the ability concept became complicated in the metropolitan area as it involves issues like price and quality of the house, household income distribution, the ability of the household to repay housing loan, policies that affect the housing sector, and willingness to pay for a house. The house prices that increased exceeding the income distribution has limited the ability of households to purchase a house [12].

Tan \& David (2013) stressed that there is a mismatch between demand and supply in Johor Bahru housing market [13]. On top of that, the property market report also stated that the residential property transaction has become weak since the year 2015. However, a housing development in the area is increasingly progressive over the period and has led to housing market imperfection. Bloch (1997) agreed that government intervention is mainly needed in tackling this critical issue. Hence, the purpose of this paper is to understand the housing market function and explore the government intervention in the housing market [14].

\section{HOUSING MARKET FUNCTION}

According to Miller \& Geltner (2005), Maclennan (2012) and Harvey \& Jowsey (2004), the market is the mechanism that involves the exchange of product and services between a willing buyer and a willing seller. Meanwhile, the housing market is a place where the transaction of ownership which include vacant land, agriculture, building, offices, commercial and residential land, between buyer and seller $[15,16,17]$. Besides that, AHURI (2015) argue that the housing market is different if compared to other markets. The differences are based on the location, type of houses and tenure, age of the building, quality and financing [18].

The role of the housing market is to provide a complete information about the latest condition of the property market which relates to demand and supply that influenced by house rent and price. Usually, people refer to the housing market to get the information regarding the current market situation. 
Besides that, the balance between demand and supply also can determine the market. Prospective buyers often looking for affordable houses in the market and the transaction activity in the market is one of the key information they need from property market report $[17,19]$.

\section{MARKET EQUILIBRIUM}

The housing market is mainly said in perfect condition if it contains information, price, competition and access model in the market [20]. According to Barlowe (1978), the demand and supply curve has to be at the equilibrium point for the market to be efficient. The interaction between demand and supply is the key to market efficiency [21].

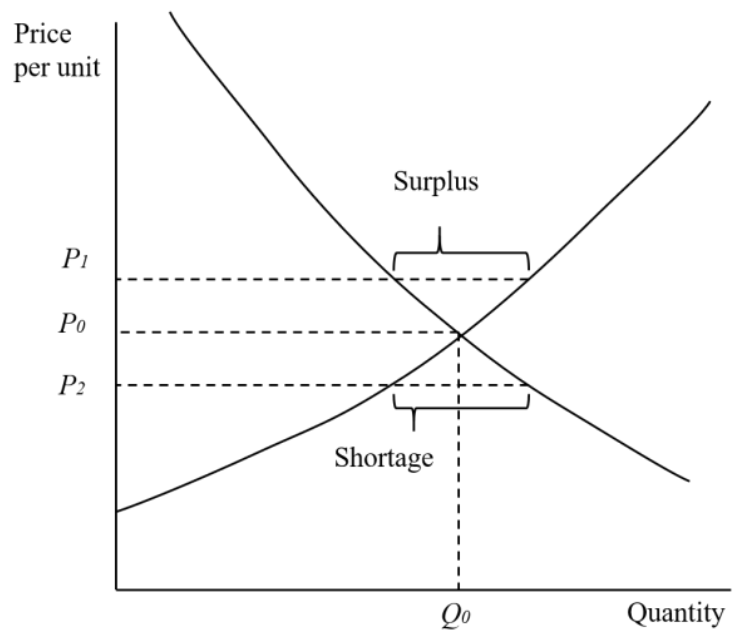

Figure 1. Price Equilibrium Point ${ }^{21}$

Figure 1 shows the relationship between demand and supply in the housing market. Price is an important mechanism that determines the balance between demand and supply ${ }^{22}$. It could be the movement of the curves that determine the house price. The figure also shows that, if the point going upward from $\mathrm{P} 0$ to $\mathrm{P} 1$, the price will increase and the surplus will happen. It is when there is a lot of housing stock in the market but unsold due to the high price. When the price is high, people cannot decide to buy a house because of the limit from their income distribution. Thus, when surplus happens, price tends to fall to enable people to buy for a house. When that happens, the fallen price will ensure the point to reach its equilibrium point again ${ }^{21}$.

Oppositely, if the point going downward from P0 to P2, the price will fall and caused a shortage. Meaning that there is less housing supply in the market. At the same time, people eagerly looking for a house because of the low price. Demand increased more than supply and it cannot be covered by the total of housing stock in the market. To solve the problem, prices tend to rise to reduce the demand and to ensure the point can reach the equilibrium point (Q0P0). The surplus and shortage matter shows that the housing market is exposed to externalities which will affect the market efficiency. This also brings the meaning that surplus and shortage in the market are signs of housing market imperfection. In simple words, demand and supply play the biggest role in housing market condition $^{21}$.

\section{GAP BETWEEN DEMAND AND SUPPLY}

The imperfection of the housing market is due to the existence of the gap between demand and supply. House price is strongly related to demand and supply. This paper will discuss two aspects that influence the gap which is house price and income distribution. According to Harvey (1981), the house price in the market was determined by demand. House price is not constant at a certain time. It depends on the current price in the market. The developer used the highest current house price in the market as a benchmark for new housing development. At the same time, the current price also influences the developer's decision in choosing a land resource. They will need the highest and best use land resources to make new development [23]. However, other than a profitable project, developers often think about the costs that will be involved. Largest costs needed for the development caused by higher house price. That is because the costs involved will be absorbed to house price and incurred by prospective buyers [17].

Housing is the largest expenses for every household as they need to spend a lot of money every month. Most of the household income used to pay for housing loan $[9,10]$. Davenport (2003) stated that housing loan expenditure is the biggest expenses ever whereas household also need to spend their income for other necessities [24]. According to Khazanah Research Institute report, the household spends $48.6 \%$ of their income for housing. Meanwhile, the Central Bank of Malaysia (BNM) also stated that the bottom $40 \%$ income group have the most obligations to pay for a housing loan. This shows that the bottom $40 \%$ of income groups are vulnerable to the price and income changes.

In Malaysia, there are only $20 \%$ of people with the highest income group compared with the rest of $80 \%$ is a middle and low-income group. The ability of households to own a home is measured based on their ability to pay the housing loans. In the circumstances where home prices continue to rise, the distribution of household income becomes a barrier to qualifying for house purchasing. In Johor, housing construction is increasing, and the developer's target is foreign buyers such as Singaporean, but few are interested. The highest-income 20 per cent are not able to buy more units on the market as they only need a unit for the family. The unsold housing stock in the market indicates the market inefficiency especially if the stocks stay in the market for a long time. The level of housing affordability ratio has increased from 3.65 to 4.17 in the year 2014 primarily due to the increases in house price growth of 39.42 per cent in 2014.

\section{GOVERNMENT INTERVENTION IN HOUSING MARKET}

Government intervention is necessary to correct market failure. Bloch (1997) stated that the volatility of house price need government intervention involvement [14]. According to Belsky \& Wachter, (2010), Quigley \& Raphael (2004), Hulchanski (2003) and Atterhog (2005), government intervention could be implemented through policies, 
regulations, or programs [12,25,26,27]. Musgrave \& Musgrave (1980) stated that there are three types of policies. First is the stabilization policy where the government uses monetary and fiscal policy to control the unemployment rate and inflation, second is the income distribution policy, and lastly is resource allocation to developers per development needs.

The government may correct the inefficient market by providing more affordable housing [29]. This is to ensure that people are able to own a house, especially for the bottom $40 \%$ income group. Subsidizing house price also one of the initiatives that can promote affordable houses [30]. In short, the subsidy is an incentive given by the government to attract developers and buyers attention so that they can build and buy a house with a low price. The government in Ireland are renewing the stamp duty policy to control speculation activities in the housing market [31]. In Singapore, the government provides affordable houses at a low price and low loan of interest rates. Other than that, buyers also allowed to use their saving from the Central Provident Fund scheme for the down payment and monthly mortgage [32]. The housing system in Singapore is a good example of controlling the house price in the market [33].

Bertaud (2012) clarified that the government sector in India and Thailand has responsibilities in giving housing allowance to the needed and demolished squatters [34]. In the Malaysia context, market dips when higher RPGT rates are imposed as can be seen by softening of the market activities between 2011 and 2013. Simultaneously, accommodative financial environment facilitates the market to sustain the house prices even when the RPGT rates peak at 30 per cent. Average House Price from MHPI moves positively annually in the past 10 years [35]. Hence, the housing sector needs certain levels of government intervention to ensure healthy economic growth and for the community well-being.

\section{CONCLUSION}

The boom and burst of the real estate market are believed to have been caused by speculative bubbles that have led to the increases in house price and further create instability in the financial system and inconsistency in capital accumulation. The literature identifies the geographical location, macroeconomic factors, demography factor, and land and zoning as the factors that influence the housing prices. As the literature identifies, government policy plays a strong role in housing supply responsiveness to meet the underlying demand. Government policy interventions are necessary to tackle the market imperfection. There is a need for improved efficiency, collaboration and mechanisms to improve housing delivery to reducing the gap between supply and demand. The local housing strategy model is an effective vehicle for the governments to address defined housing needs and objectives. The study showed local governments need tools and a range of mechanisms and policy responses that could be adapted to assist them to achieve their housing strategies. Developing and enabling these tools would be a valuable for governments, in particular planning or housing departments. The most critical need is for legal mechanisms for retaining, promoting, financing, or providing affordable housing or homes for vulnerable groups. Further investigation for the factor influencing the imperfect housing market dimensions is needed to provide adequate exploration for legislative bodies as well as academic institutions, to design a better policy or blueprint that can enhance the development of the housing sector in Malaysia.

\section{ACKNOWLEDGMENT}

This work was supported by Ministry of Education and Universiti Teknologi Malaysia under the Research University Grant (GUP), Vot. 17J18.

\section{REFERENCES}

1. Jiram, W. R. A., Bujang, A. A., Zairuslan, I. A., \& Zarin, H. A 2016. The evaluation of physical and environmental factors in low-cost housing. In Knowledge, Service, Tourism \& Hospitality: Proceedings of the Annual International Conference on Management and Technology in Knowledge, Service, Tourism \& Hospitality 2015 (SERVE 2015), Bandung, Indonesia, 1-2 August 2015 (p. 139). CRC Press.

2. Maslow, A. H. 1943. A theory of human motivation. Psychological review, 50(4), 370

3. Aziz, W.A.W.A., N.R. Hanif, \& K.a.l. Singaravello. 2011. A Study on Affordable Housing Within the Middle Income Households in the Major Cities and Town in Malaysia, National Institute of Valuation (INSPEN): Kuala Lumpur.

4. Gan, Q., \& Hill, R. J. 2009. Measuring housing affordability: Looking beyond the median. Journal of Housing economics, 18(2), 115-125.

5. Azmi, N., Bujang, A. A., Jiram, W. R. A., \& Zarin, H. A. 2016. The fundamental of housing affordability and affordable houses: A review. In Knowledge, Service, Tourism and Hospitality Proceedings of the Annual International Conference on Management and Technology in Knowledge, Service, Tourism and Hospitality, SERVE 2015 (pp. 203-208). CRC Press/Balkema.

6. Azmi, N., Bujang, A. A., Jiram, W. R. A., \& Zarin, H. A. 2015. Mismatch between housing affordability and affordable houses in Malaysian property market: A review. In Economics, Social Sciences and Information Management: Proceedings of the 2015 International Congress on Economics, Social Sciences and Information Management (ICESSIM 2015), 28-29 March 2015 Bali, Indonesia (p. 125). CRC Press.

7. Bujang, A. A., Jiram, W. A., Zarin, H. A., \& Anuar, F. M. 2015 Measuring the Gen Y housing affordability problem. International Journal of Trade, Economics and Finance, 6(1), 22

8. Bujang, A. A., Ismail, A. B., Zarin, S. H. A., \& Jiram, W. R. A 2015. Single mother housing affordability. In Proceedings of the 25th International Business Information Management Association Conference - Innovation Vision 2020: From Regional Development Sustainability to Global Economic Growth, IBIMA 2015 (pp. 3729-3738). International Business Information Management Association, IBIMA.

9. Bujang, A., Jiram, W. A., Zarin, H. A., \& Jaafar, M. N. 2015 Factor Affecting the Housing Financing of Bumiputera in Iskandar Malaysia. Journal of Economics, Business and Management, Vol 3, No. 11, November

10. Ismail, A., Bujang, A. A., Jiram, W. A., Zarin, H. A., \& Jaafar, M N. (2015). Housing Financing Facility and Affordability Level of Bumiputera within Iskandar Malaysia. Journal of Economics, Business and Management, 3(9).

11. Agus, M. R. 2003. The Impact of Government Intervention on the Housing Market in Malaysia. The Journal of Comparative Asian Development, 2(1), 133-149.

12. Quigley, J. M. and S. Raphael. 2004. "Is housing unaffordable? Why isn't it more affordable?" The Journal of Economic Perspectives 18(1): 191-214.

13. Tan, J. P., \& David, M. 2013. State of the current property market in relation to the property bubble phenomenon in Johor. 
14. Bloch, B. 1997. Volatility in the residential housing market: an international perspective. Property Management, 15(1), 12-24.

15. Miller, N. G., \& Geltner, D. 2005. Real estate principles for the new economy. Thomson/South-Western.

16. Maclennan, D. 2012. Understanding housing markets: real progress or stalled agendas. The SAGE handbook of housing studies, 5-26.

17. Harvey, J., \& Jowsey, E. 2004. Urban land economics. Palgrave Macmillan.

18. Gurran, N., Phibbs, P., Yates, J., Gilbert, C., Whitehead, C., Norris, ,M., McClure, K., Berry, M., Maginn, P., Goodman, R. (2015) Housing markets, economic productivity, and risk: international evidence and policy implications for Australia Volume 1: Outcomes of an Investigative Panel, AHURI Final Report No. 254, Australian Housing and Urban Research Institute Limited, Melbourne, https://www.ahuri.edu.au/research/final-reports/254

19. Bourne, L. S. 1981. The geography of housing. London: VH Winston.

20. Bayer, P., McMillan, R., \& Rueben, K. (2004). An equilibrium model of sorting in an urban housing market (No. w10865). National Bureau of Economic Research.

21. Barlowe, R. 1978. Land Resource Economics: The Economics of Real Property 3rd edition, Prentice-Hall, Englewood Cliffs, NJ, pp.23

22. Gale, D. 1955. The law of supply and demand. Mathematica scandinavica, 155-169.

23. Harvey, J. 1981. The economics of real property. Macmillan.

24. Davenport, J. 2003. The Effect of Supply and Demand Factors on the Affordability of Housing.

25. Belsky, E. S., \& Wachter, S. 2010. The need for government intervention to protect and advance the public interest in consumer and mortgage credit markets. Joint Center for Housing Studies. Boston: Harvard University./ http://www. jchs. harvard. edu/sites/jchs. harvard. edu/files/mf10-15. pdf.

26. Hulchanski, J. D. 2003. "What factors shape Canadian housing policy? The intergovernmental role in Canada's housing system." Municipal-federal-provincial relations in Canada.

27. Atterhög, M. 2005. "Importance of government policies for home ownership rates: an international survey and analysis."

28. Musgrave \& Musgrave (1980)

29. Bertaud, A. 2012. Government intervention and urban land markets: the case of China. Journal of Architectural and Planning Research, 335-346.

30. Hoek-Smit, M. C., \& Diamond, D. B. 2003. Subsidies for housing finance. Housing Finance International, 17(3), 3 .

31. Berry, J., McGreal, S., Stevenson, S., \& Young, J. 2001. Government intervention and impact on the housing market in Greater Dublin. Housing Studies, 16(6), 755-769.

32. Chiu, R. L. 2008. "Government intervention in housing: Convergence and divergence of the Asian Dragons." Urban Policy and Research 26(3): 249-269.

33. Phang, S. Y., \& Wong, W. K. 1997. Government policies and private housing prices in Singapore. Urban studies, 34(11) 1819-1829.

34. Bertaud, A. 2012. Government intervention and urban land markets: the case of China. Journal of Architectural and Planning Research, 335-346.

35. Zailan, M.I. 2014. Real Property Gains Tax and the Malaysian Housing Market. FIG Congress 2014 Engaging the Challenges, Enhancing the Relevance Kuala Lumpur, Malaysia, 16 - 21 June.

\section{AUTHORS PROFILE}

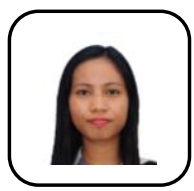

Normi Abdul Asis graduated with Bachelor of Science in Property Management at University Teknologi Malaysia. Currently work as a Valuation Executive at Rahim \& Co International Sdn. Bhd, Kota Kinabalu.

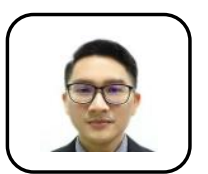

Wilson Rangga Anthony Jiram is a Senior Lecturer at Universiti Teknologi Malaysia. His research interests lie in the real property of Malaysia, particularly property market, economics, and property surveying competencies. Currently writing and carrying out research on housing liveability, affordability, and wellbeing.

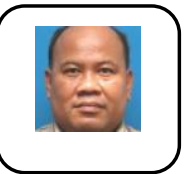

Ahmad Ariffian Bujang was an Associate Professor at Universiti Teknologi Malaysia. Hi research interests lie in the real property of Malaysia, particularly housing economics, and property market. 